\title{
non-white 入力を受ける履歴型多質点系のランダム応答解析
}

$\begin{array}{lllll}\text { 正会員 } & \text { 和 } & \text { 泉 } & \text { 正 } & \text { 哲* } \\ \text { 正会員 } & \text { 木 } & \text { 村 } & \text { 正 } & \text { 彦** }\end{array}$

\section{1. 序}

建築構造物の耐震構造安全性評価において, 入力地震 動の不確定性を考慮した構造物モデルの応答解析が必要 であるとの視点から，筆者らは文献 1)，2）においてマ ルコフ連鎖確率モデルを用いた履歴系のランダム応答を 求める解析手法を展開し，それらを定常および振幅非定 常な Gaussian white noise を受ける完全弾塑性型 1 質 点系の非定常ランダム応答を求める場合に適用してき た。この手法は, 荷重-変位 $(\boldsymbol{P}-\boldsymbol{\delta})$ 平面を有限個の領 域に分割することにより $P-\delta$ 平面上の応答位置を離散 化し，これらの離散化された応答位置を応答の状態量と みなし，これらの状態上に応答が存在する確率分布（確 率関数）を非定常に求めることを基本とする。そして, この確率分布の推移に対してマルコフ連鎖を仮定し，応 答の状態間の期待推移回数により規定される推移マト リックスを求めることにより，応答の状態上の確率分布 を非定常に求めるのである。この手法によれば，同時に 最大応答および極值応答の確率分布，初通過破壊確率を も容易に求めることができる。

ところで，履歴系のランダム応答に関する研究におい ては，一部の研究 (文献 3)，4)）を除いて入力を white noise としているのがほとんどである。しかしながら， 一般に建築構造物の受ける地震動が，地盤の存在等によ り non-white 性を示すことを考えると，入力として non-white noise を対象とする必要がある。また，非線 形性の強い履歴型多質点系のランダム応答を，質点数が 増えても効率よく求められることが望ましい。本報告で はこれらの点を鑑み、マルコフ連鎖確率モデルによる履 歴系のランダム応答解析手法を, non-white noise の一 種である振幅非定常な filtered Gaussian white noise を 受ける，Bilinear 型多質点せん断系に適用する場合の理 論的拡張およびそれら理論解と Monte Carlo 法による シミュレーション解との比較検討を行う。

\section{2. 解析手順}

* 東北大学 教授・工博

** 東北大学 大学院生 (昭和 59 年 4 月 10 日原稿受理日, 昭和 59 年 8 月 6 日改訂原稿受理 日，討論期限昭和 60 年 4 月末日）
マルコフ連鎖確率モデルにより履歴型質点系のランダ 么応答解析を行う場合の手順は，以下のようにまとめる ことができる(文献 1))。

1) $P-\delta$ 平面を, 履歴特性を考慮して有限な $n$ 個の 領域

$\mathbf{S}=\left\{S_{1}, S_{2}, \cdots, S_{i}, \cdots, S_{n}\right\}$

に分割し，これらを応答の状態量とみなす。

2）時刻 $t$ に応答が状態 $S_{i}$ （または単に状態 $i$ と呼 ぶ）に存在している確率を $P_{i}(t)$ として, ベクト ル $\boldsymbol{P}(t)$ を次のごとく定義する。 $\boldsymbol{P}(t)=\left\{P_{1}(t), P_{2}(t), \cdots, P_{i}(t), \cdots P_{n}(t)\right\}$ $\boldsymbol{P}(t)$ は応答の状態 $\boldsymbol{S}$ 上の確率分布（確率関数） そのものであり,応答べクトルと呼ぶことにする。

3）初通過破壞の基準となる応答の状態を定める。

4）初期状態における応答の状態 $\boldsymbol{S}$ 上の応答べクト ル $\boldsymbol{P}\left(t_{0}\right)$ を設定する。

5）応答の状態 $i$ から $j$ への単位時間当たりの期待 推移回数 $\mu_{i j}\left(t_{m}\right)$ を設定する。

6) 時点 $t_{m}$ から $t_{m+1}$ への推移マトリックス $\pi^{\iota_{m} t_{m+1}}$ を $\mu_{i j}\left(t_{m}\right)$ に基づき作成する。 $\mu_{t j}\left(t_{m}\right)(i, j=1 \sim n)$ を $i j$ 要素とするマトリックスを $\boldsymbol{A}\left(t_{m}\right)$ とおくと $\pi^{t_{m} t_{m+1}}$ は

$$
\begin{aligned}
\pi^{t_{m} t_{m+1}} & =\exp \left(\int_{t_{m}}^{t_{m+1}} A(\tau) d \tau\right) \\
& \fallingdotseq \exp \left\{A\left(t_{m}\right)\left(t_{m+1}-t_{m}\right)\right\}
\end{aligned}
$$

と表すことができる。

7）時点 $t_{m}$ における応答の状態 $\boldsymbol{S}$ 上の応答ベクトル $\boldsymbol{P}\left(t_{m}\right)$ （ $n$ 次の行ベクトル）に推移マトリックス $\boldsymbol{\pi}^{t_{m} t_{m+1}}(n$ 次の正方マトリックス) を掛けること により, $\boldsymbol{P}\left(t_{m+1}\right)$ を求める。

$$
\boldsymbol{P}\left(t_{m+1}\right)=\boldsymbol{P}\left(t_{m}\right) \boldsymbol{\pi}^{t_{m} t_{m+1}}
$$

8）5－7）の手順を入力の継続時間 $t_{m_{0}}$ にしたがい, $m=0 \sim\left(m_{0}-1\right)$ において繰り返す。

従って，基本的には履歴系が多質点系であっても，各 質点ごとに応答の状態間での単位時間当たりの期待推移 回数 $\mu_{i j}(t)$ を適切に設定することができれば，各質点ご とに独立に確率応答 $\left.\boldsymbol{P}\left(t_{i}\right) （ i=1 \sim m_{0}\right)$ を算出すること ができるわけである。ここで問題となるのは，この手法 
を対象としている履歴系に適用する場合に，応答の状態 間での単位時間当たりの期待推移回数 $\mu_{t j}(t) \quad(i, j=1$ 一n) すなわちマトリックス $A(t)$ をいかに設定するか である。この $\boldsymbol{A}(t)$ には, 入力と履歴系の特性が非定常 に取込まれなければならない。

本論で対象とする，振幅非定常な filtered Gaussian white noise を受ける Bilinear 型多質点せん断系におい ては，次に述べるごとく $\mu_{i j}(t)$ を設定するものとする。

まず $k$ 質点の荷重-層間変位 $\left(P_{k}-\delta_{k}\right)$ 平面を Fig. 1 のように $n$ 個の領域に分割し, 状態 1 および状態 $n$ を 初通過破壊の基準とする。この質点の応答の状態 $i$ から $j へ$ の単位時間当たりの期待推移回数 ${ }_{k} \mu_{i j}(t)$ は, 既報

(文献 1)，2））の場合と同様に, 状態 $i$ に対応づけら れた線形系 ${ }_{k} L_{\iota}$ (Fig. 2 参照) に関する䦨值横断問題か ら近似するものとする。この閥値は, Bilinear 系のエネ ルギー一定則に基づき状態 $i$ と状態 $j$ の幾何学的関係 から決定される。

このようにして与えられる $\mu_{k j}(t)$ は，次のように整 理される(文献 1))。

a. $\begin{aligned}(i=2 \sim n-1, j \neq i, 1, n) \\ { }_{k} \mu_{i j}(t)={ }_{k} \nu_{j 1}^{+}(t)-{ }_{k} \nu_{j 2}^{+}(t) \cdots \cdots . . .\end{aligned}$

b. $(i=2-n-1, j=1, n)$

${ }_{k} \mu_{t j}(t)={ }_{k} \nu_{j 1}^{+}(t)$

c. $(i=1, n, j \neq i)$

${ }_{n} \mu_{t j}(t)=0$

d. $(i=1 \sim n)$

$$
{ }_{k} \mu_{i l}(t)=-\sum_{j \neq i}{ }_{k} \mu_{i j}(t)
$$

(5) - (8) 式に出てくる ${ }_{k} \nu_{j 1}^{+}(t),{ }_{k} \nu_{j 2}^{+}(t)$ は, 平均值 0 の定常ガウス過程が Fig. 2 に示されるような線形系 ${ }_{k} L_{t}$ の変位上の闎值 ${ }_{k} x_{j 1},{ }_{k} x_{j 2}$ を，単位時間当たりに正 勾配で横断する期待回数の形で表せるものとする。この 閾値 ${ }_{k} x_{j 1},{ }_{k} x_{j 2}$ は, 弾望性応答亡線形弾性応答のポテン シャルエネルギーを等置することによって，Fig. 2 に示 されるごとく状態 $i$ と状態 $j$ の幾何学的関係から定め

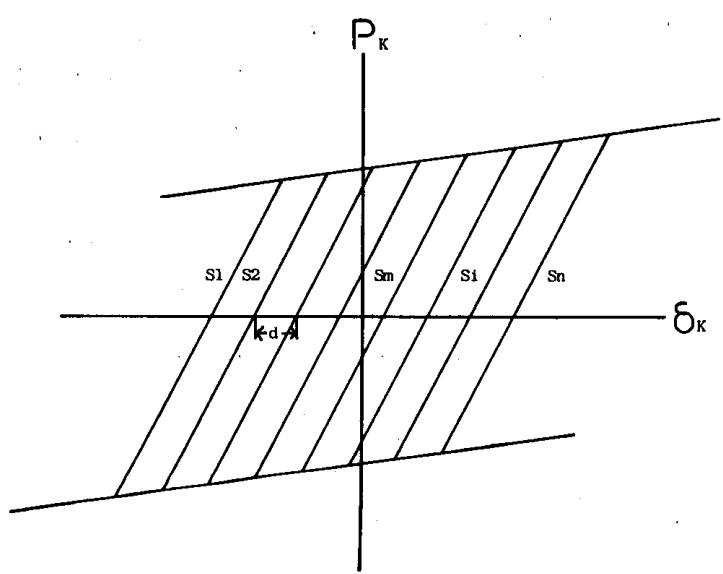

Fig.1 Discretized Response-State.
る。閾値を一般に ${ }_{k} x_{\lambda}$ とすれば, ${ }_{k} \nu_{\lambda}^{+}(t)$ は次式のごとく 表現される。

$$
{ }_{k} \nu_{\lambda}^{+}(t)=\frac{{ }_{k} \bar{\sigma}_{\dot{x}}\left(T_{0}(t)\right)}{2 \pi_{k} \bar{\sigma}_{x}\left(T_{0}(t)\right)} \cdot \exp \left\{-\frac{{ }_{k} x_{\lambda}^{2}}{2{ }_{k} \bar{\sigma}_{x}^{2}\left(T_{0}(t)\right)}\right\}
$$

ここに $T_{0}(t)$ は, 入力である filtered Gaussian white noise $z(t)$ の時刻 $t$ におけるレベル $I(t)$ により規定さ れる量であり，対応する線形系 CLS $(t)$ (corresponding linear system)（後述）が零初期条件のもとでレベル $I(t)$ なる定常な filtered Gaussian white noise $z_{0}(\tau)$ を 受けた場合の ${ }_{k} L_{i}$ の非定常出力応答 $x(\tau)$ が状態 $i$ に平 均的に滞在している時間を意味する。(9) 式における ${ }_{k} \bar{\sigma}_{x}\left(T_{0}(t)\right),{ }_{k} \bar{\sigma}_{\dot{x}}\left(T_{0}(t)\right)$ は，それぞれこの $x(\tau), \dot{x}(\tau)$ の標 準偏差応答 ${ }_{k} \sigma_{x}(\tau),{ }_{k} \sigma_{\dot{x}}(\tau)$ を $\left[0, T_{0}(t)\right]$ において時間平 均したものである。 $T_{0}(t)$ は

$$
2 \int_{0}^{T_{0}(t)} N_{y}^{+}(I(t) ; \tau) d \tau=1
$$

として，状態 $i$ が他の状態に移行する場合の基準となる 閥値 $x_{y}$ (Fig. 3 参照) を $x(\tau)$ が超過する期待回数が 1

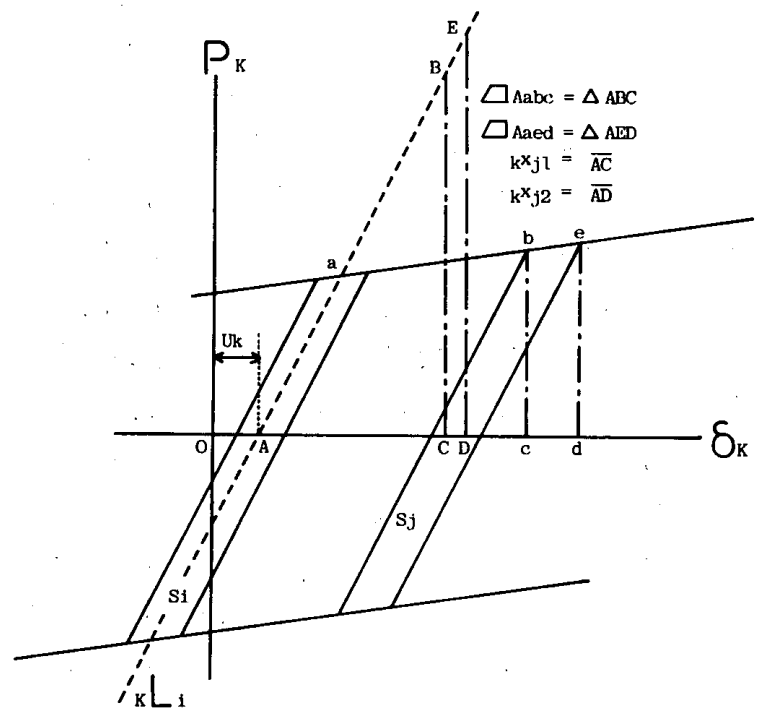

Fig. 2 Threshold Values ${ }_{k} x_{j_{1}}$ and ${ }_{k} x_{j 2}$ associated with ${ }_{k} \mu_{i j}$.

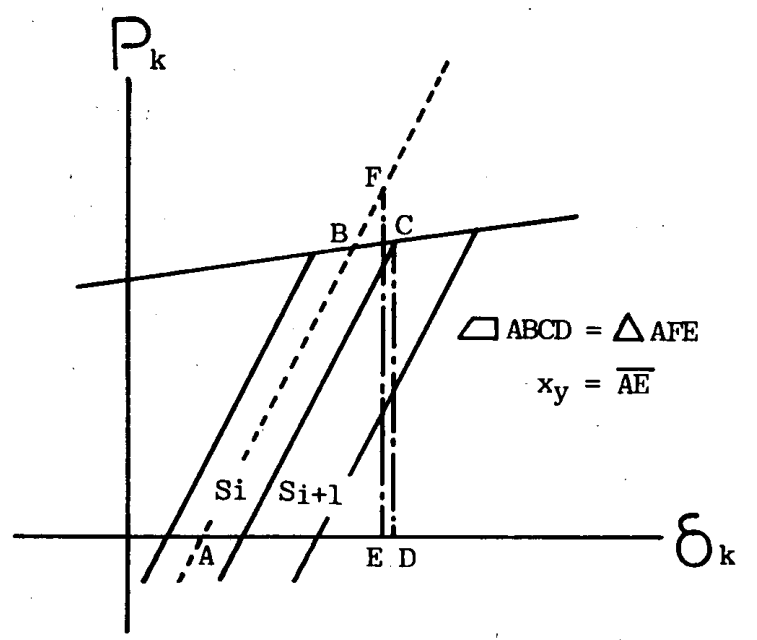

Fig. 3 Threshold Value $x_{y}$ associated with Eq. (10). 
となる時間をもって定める。ここに $N_{y}^{+}(I(t) ; \tau)$ は, $x(\tau)$ が閾值 $x_{y}$ を単位時間当たりに正勾配で横断する期 待回数である。

前述の ‘対応する線形系” $C L S(t)$ とは, 時刻 $t$ におけ る Bilinear 型多質点せん断系 $N L S(t)$ の各質点の応答 が状態 $i(k, t)(k=1 \sim K, K$ : 質点数) であるとき, これらの状態に対応する線形系 ${ }_{k} L_{i}$ から構成される線形 多質点せん断系を指す。すなわち, CLS $(t)$ とは $N L S(t)$ の各質点の応答の状態 $i(k, t)(k=1 \sim K)$ に 関して定まる層間塑性変形 $U_{k}(t)$ (Fig. 2 参照) を介して, ${ }_{k} L_{i}$ をせん断型に結合した線形系である。

ところで, この $C L S(t)$ は, 各 ${ }_{n} L_{i}$ 上の原点 (Fig. 2 の A 点) からの変位, 速度を状態変数として運動方程式を たてると,この運動方程式は, $U_{\boldsymbol{k}}(t)$ のない場合の線形 多質点せん断系 $C L S O(t)$ の層間変位, 層間速度に関す る運動方程式と等価になるので, ${ }_{k} \sigma_{x}(\tau),{ }_{k} \sigma_{\dot{x}}(\tau)$ は $C L S O(t) の k$ 質点の層間変位, 層間速度の標準偏差応 答として求めることができる。

定常 filtered Gaussian white noise $z_{0}(\tau)$ は, $w\left(\tau_{0}\right)$ を パワースペクトルレベル $S_{0}(t)$ の定常 Gaussian white noise とすると, 以下のように $w\left(\tau_{0}\right)$ を受ける線形 1 自 由度系の絶対加速度応答の定常部分として表される（文 献 5))。

$$
\begin{aligned}
& \ddot{u}+2 h_{\mathbf{g}} \omega_{\mathrm{g}} \dot{u}+\omega_{\mathrm{g}}^{2} u=-w\left(\tau_{0}\right) \\
& z_{1}\left(\tau_{0}\right)=\ddot{u}\left(\tau_{0}\right)+w\left(\tau_{0}\right) \\
& z_{0}(\tau)=z_{1}(\tau) \\
& \tau=\tau_{0}-\tau_{0 c o} \quad(\tau \geqq 0) \text {. } \\
& \tau_{0 c o} \geqq 1 /\left(h_{\boldsymbol{g}} \omega_{\boldsymbol{g}}\right)
\end{aligned}
$$

従って, $z_{0}(\tau)$ のレベル $I(t)$ を示す指標として $w\left(\tau_{0}\right)$ の パワースペクトルレベル $S_{0}(t)$ を用いることができ，以 後 $S_{0}(t)$ をもって $I(t)$ を表すものとする。

次にレベル $I(t)=S_{0}(t)$ なる定常 filtered Gaussian white noise $z_{0}(\tau)$ を受けるCLSO (零初期条件) の $k$ 質点の層間変位, 層間速度の標準偏差応答 ${ }_{k} \sigma_{x}(\tau)$, ${ }_{k} \sigma_{\dot{x}}(\tau)$ を示す。一般に ${ }_{k} \sigma_{x}(\tau),{ }_{k} \sigma_{\dot{x}}(\tau)$ は, 次式のように 表現することができる。

$$
\begin{aligned}
& { }_{k} \sigma_{x}^{2}(\tau)={ }_{k} \sigma_{x s}^{2}\left(1-g_{x}(\tau)\right) . \\
& { }_{k} \sigma_{\dot{x}}^{2}(\tau)={ }_{k} \sigma_{\dot{x} s}^{2}\left(1-g_{\dot{x}}(\tau)\right) .
\end{aligned}
$$

ここに ${ }_{k} \sigma_{x s},{ }_{k} \sigma_{\dot{x} s}$ は, それぞれ $k$ 質点の層間変位, 層 間速度の標準偏差応答の定常值である。 $g_{x}(\tau), g_{\dot{x}}(\tau)$ は 過渡応答性状を表す部分で, $\tau$ の增加とともに 1 から 0 へ変調しながら減少していく関数である。 ${ }_{k} \sigma_{x s},{ }_{k} \sigma_{\dot{x} s}$ は, 線形システムの周波数領域における入出力間の関係およ びパワースペクトル密度関数と二乗平均値の関係から解 析的に求めることができる(文献 6))。一方, S. Krenk, H. O. Madsen and P.H. Madsen (文献 7)) は, 定常 過程を受ける零初期条件下の線形 1 自由度系において,
応答変位の基準化された標準偏差応答 $\left(\sigma_{x}(\tau) / \sigma_{x s}\right)$ の過 渡応答性状が入力のスペクトル内容にほとんど独立であ り，主に系の減衰定数に依存することを, white noise 入力と filtered white noise 入力の場合を例として確認 している。以上の点から本法では, 線形多質点系 CLSO の応答に最も支配的なモードの基準座標が white noise 入力を受けた場合に示す次式（文献 8)）に より, (16), (17) 式の $g_{x}(\tau), g_{\dot{x}}(\tau)$ を近似するものと する。

$$
\begin{aligned}
& g_{x}(\tau)=\exp \left(-2 h \omega_{0} \tau\right) \mid 1+2 r^{2} \sin ^{2}\left(\omega_{d} \tau\right) \\
& +r \sin \left(2 \omega_{d} \tau\right) \\
& g_{\dot{x}}(\tau)=\exp \left(-2 h \omega_{0} \tau\right)\left(1+2 r^{2} \sin ^{2}\left(\omega_{d} \tau\right)\right. \\
& \left.-r \sin \left(2 \omega_{d} \tau\right)\right\} \\
& r=h / \sqrt{1-h^{2}}
\end{aligned}
$$

ここに, $h, \omega_{0}, \omega_{d}\left(=\omega_{0} \sqrt{1-h^{2}}\right)$ のーダルパラメータは, それぞれ減衰定数, 非減衰固有円振動数, 減衰固有円振 動数である。これらのパラメータ值としては, Bilinear 型多質点せん断系 $N L S$ の粘性诚衰係数を, NLS の質 量および第 1 剛性分布から剛性比例型で与えることを前 提に, 線形系 CLSO の 1 次のモーダルパラメータ值を 使用する。このように設定する理由は以下のごとくであ る。まず，Bilinear 型の履歴系は剛性低下を考えていな いので, 線形系 CLSOにおいてもその減衰係数は剛性 比例型の形を保存している。そして, 剛性比例型の減衰 係数を有する線形多質点系においては，(18），(19）式 の $\boldsymbol{g}_{\boldsymbol{x}}(\boldsymbol{\tau}), \boldsymbol{g}_{\dot{x}}(\tau)$ の減衰性状を最も規定する $h \omega_{0}$ の項の 值が, 1 次モ一ドの場合に最小值をとるので, この線形 系の過渡応答性は 1 次モードによりほとんど支配され る。従って，(18), (19) 式右辺の $h, \omega_{0}$ として線形系 CLSO の 1 次のモーダルパラメータ值を用いることが 許容されるのである。

(10) 式における $N_{y}^{+}(I(t) ; \tau)$ は, 対応する線形系 $C L S(t)$ が零初期条件のもとでレベル $I(t)$ なる定常な filtered Gaussian white noise $\boldsymbol{z}_{0}(\tau)$ を受ける場合の非定 常出力応答 $x(\tau)$ が, 閾値 $x_{y}$ を単位時間当たりに正勾配 で横断する期待回数であり, 次式のごとく表される。

$$
\begin{aligned}
& N_{\dot{y}}^{+}(I(t) ; \tau)=\frac{{ }_{k} \sigma_{\dot{x}}(\tau)}{2 \pi_{k} \sigma_{x}(\tau)} \exp \left(-\frac{x_{y}^{2}}{22_{k} \sigma_{x}^{2}(\tau)}\right) \\
& \cdot\left[\sqrt{1-\rho^{2}} \exp \left(-\frac{\rho^{2} x_{y}^{2}}{2\left(1-\rho^{2}\right)_{k} \sigma_{x}^{2}(\tau)}\right)\right. \\
& \left.+\sqrt{\frac{\pi}{2 \sigma_{x}^{2}(\tau)}} \rho x_{y} \cdot\left\{1+\operatorname{erf}\left(\frac{\rho x_{y}}{\sqrt{2\left(1-\rho^{2}\right)_{k}} \sigma_{x}(\tau)}\right)\right\}\right] \\
& \rho=\frac{x_{x \dot{x}}(\tau)}{{ }_{k} \sigma_{x}(\tau)_{k} \sigma_{\dot{x}}(\tau)} \\
& \boldsymbol{x}_{x \dot{x}}(\tau)=E[x(\tau) \dot{x}(\tau)] \\
& =D \exp \left(-2 h \omega_{0} \tau\right) \sin ^{2}\left(\omega_{d} \tau\right) \text {. }
\end{aligned}
$$




$$
\begin{aligned}
& D={ }_{k} \sigma_{x}(\tau)_{k} \sigma_{\dot{x}}(\tau) \cdot 2 h /\left(1-h^{2}\right) \\
& \operatorname{erf}(x)=\frac{2}{\sqrt{\pi}} \int_{0}^{x} \exp \left(-t^{2}\right) d t
\end{aligned}
$$

ここに, $h, \omega_{0}$ は (18), (19) 式で用いられるパラメー 夕值を使う。 ${ }_{k} \sigma_{x}(\tau),{ }_{k} \sigma_{\dot{x}}(\tau)$ は, $(16),(17)$ 式で定義さ れている。

\section{3. 解析結果}

まず解析モデルについて説明する。入力は振幅非定常 な filtered Gaussian white noise であるが,これを便宜 的に確定強度関数と定常 filtered Gaussian white noise の積として表すものとする。したがって, 入力 $z(t)$ は 次式のように表される。

$$
z(t)=f(t) \zeta(t)
$$

ここに, $f(t)$ は確定強度関数で次式のように与えるも のとし，その形状を Fig. 4 に示す。

$$
\begin{aligned}
& f(t)=\left\{\begin{array}{lll}
\left(t / T_{1}\right)^{2} & \left(0 \leq t \leq T_{1}\right) \\
1 & \left(T_{1}<t \leq T_{2}\right) \\
\exp \left(-A\left(t-T_{2}\right)\right) & \left(T_{2}<t \leq T_{3}\right) \\
B\left(t-T_{4}\right)^{2}+0.05 & \left(T_{3}<t \leq T_{4}\right)
\end{array}\right. \\
& \begin{array}{l}
A=0.1609 \\
T_{4}=30
\end{array}
\end{aligned}
$$

$\zeta(t)$ は定常 filtered Gaussian white noise であり, $\zeta(t)$ のパワースペクトル形状は Fig. 5 のごとく設定し た。 $z(t)$ の継続時間は 30 秒とする。構造物モデルは, 基礎固定の Bilinear 型履歴特性を有するせん断型の 5 質点系で，クーロンスライダーを用いたW.D. Iwan（文 献 9)）による表現を用いるとFig.6のように表すこと ができる。この履歴系のシステムパラメータを Table 1 に示し，線形時モーダルパラメータをTable 2 に示す。 線形時の 1 次固有周期が 0.433 秒, 1 次の減衰定数が 0.05 (減衰係数は剛性比例型で与えた。）:゙ある。従っ て入力 $z(t)$ は，Fig. 5 に示されるごとく，対応する線 形系 (線形時の履歴系) に対して相対的に短周期成分が 卓越する入力となる。 $\zeta(t)$ のレベルは，この対応する 線形系が $\zeta(t)$ を受けた場合の 1 質点目（最下層）の定 常 r. m.s. 層間変位応答が 1 となるように, $I=S_{0}=$ $637.35 \mathrm{gal}^{2} \cdot \mathrm{sec} / \mathrm{rad}$ とした。

Table 1 Parameters of a 5-DOF Bilinear System (shear type).

\begin{tabular}{|c|c|c|c|c|c|}
\hline $\mathrm{i}$ & $\mathrm{m}_{1}$ & $\mathrm{~K}_{11}$ & $\mathrm{~K}_{21} / \mathrm{K}_{11}$ & $\mathrm{C}_{1}$ & $\mathrm{~d}_{1}$ \\
\hline 1st & 1.0 & 3000.0 & 0.1 & 20.665 & 1.0 \\
\hline 2nd & 1.0 & 2700.0 & 0.1 & 18.599 & 1.0 \\
\hline 3rd & 1.0 & 2400.0 & 0.1 & 16.532 & 1.0 \\
\hline $4 \mathrm{th}$ & 1.0 & 2100.0 & 0.1 & 14.466 & 1.0 \\
\hline 5th & 1.0 & 1800.0 & 0.1 & 12.399 & 1.0 \\
\hline
\end{tabular}

$m_{1}$ : mass of 1 th storey (tf: $\sec ^{2} / \mathrm{cm}$ )

$K_{11}$ : first stiffness of 1 th storey $(t f / c m)$

$x_{21}$ : second stiffness of ith storey $(t f / c m)$

$\mathrm{C}_{\mathrm{i}}$ : viscous damping factor of 1 th storey $(\mathrm{t} f \mathrm{sec} / \mathrm{cm})$

$d_{i}$ : ylelding displacement of ith storey $(\mathrm{cm})$

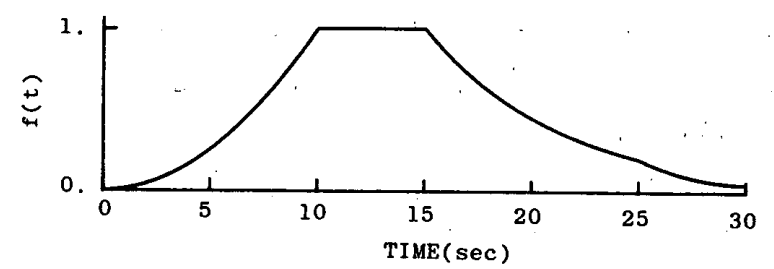

Fig. 4 Deterministic Intensity Function.

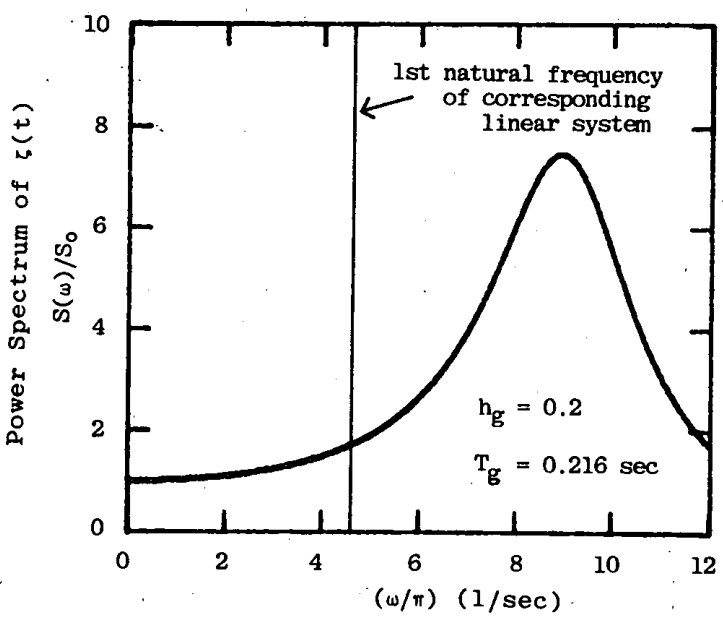

Fig. 5 Power Spectral Density Function of $\zeta(t)$.

\section{マルコフ連鎖確率モデ} ルにより導かれる解は, 応答ベクトル $\boldsymbol{P}\left(t_{i}\right)(i=1$ $\left.\sim m_{0}\right)$ である。最大応 答および極值応答の確率 分布は, $\boldsymbol{P}\left(t_{i}\right)$ が求まれ ば容易に算出され，その 精度は Monte Carlo 法 によるジュレーション 解との比較において $\boldsymbol{P}\left(t_{i}\right)$ の精度と同程度で あることが確認されてい る(文献1)，2）。した がって,ここでは応答べ クトル $\boldsymbol{P}\left(t_{t}\right)$ についての

Table 2 Modal Parameters of a Linear System Corresponding to a 5-DOF Bilinear System.

\begin{tabular}{|c|c|c|}
\hline$i$ & Ti(sec) & hi \\
\hline lst & 0.433 & 0.050 \\
\hline 2nd & 0.158 & 0.137 \\
\hline 3rd & 0.101 & 0.214 \\
\hline 4th & 0.079 & 0.275 \\
\hline 5tb & 0.066 & 0.326 \\
\hline
\end{tabular}

Ti : itb natural period hi : ith modal damping factor

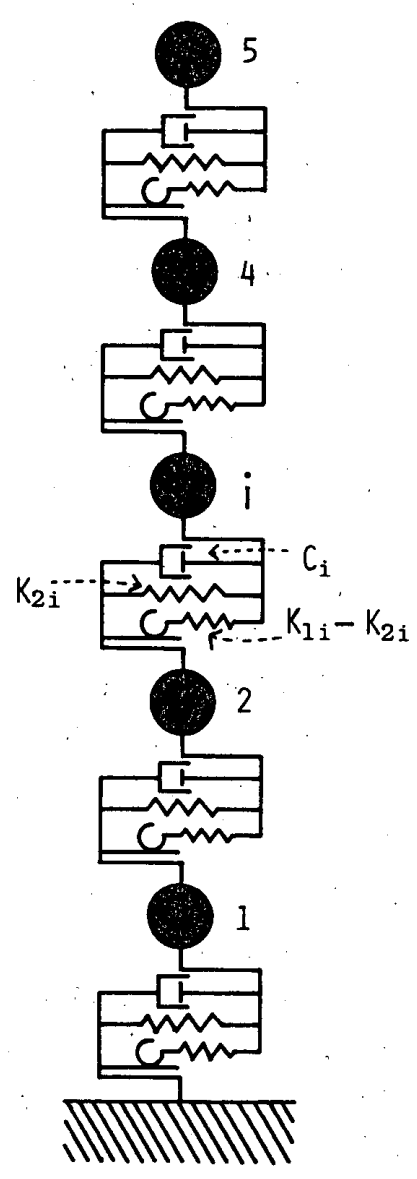

Fig. 6 Shear Type 5-DOF Bilinear System. 

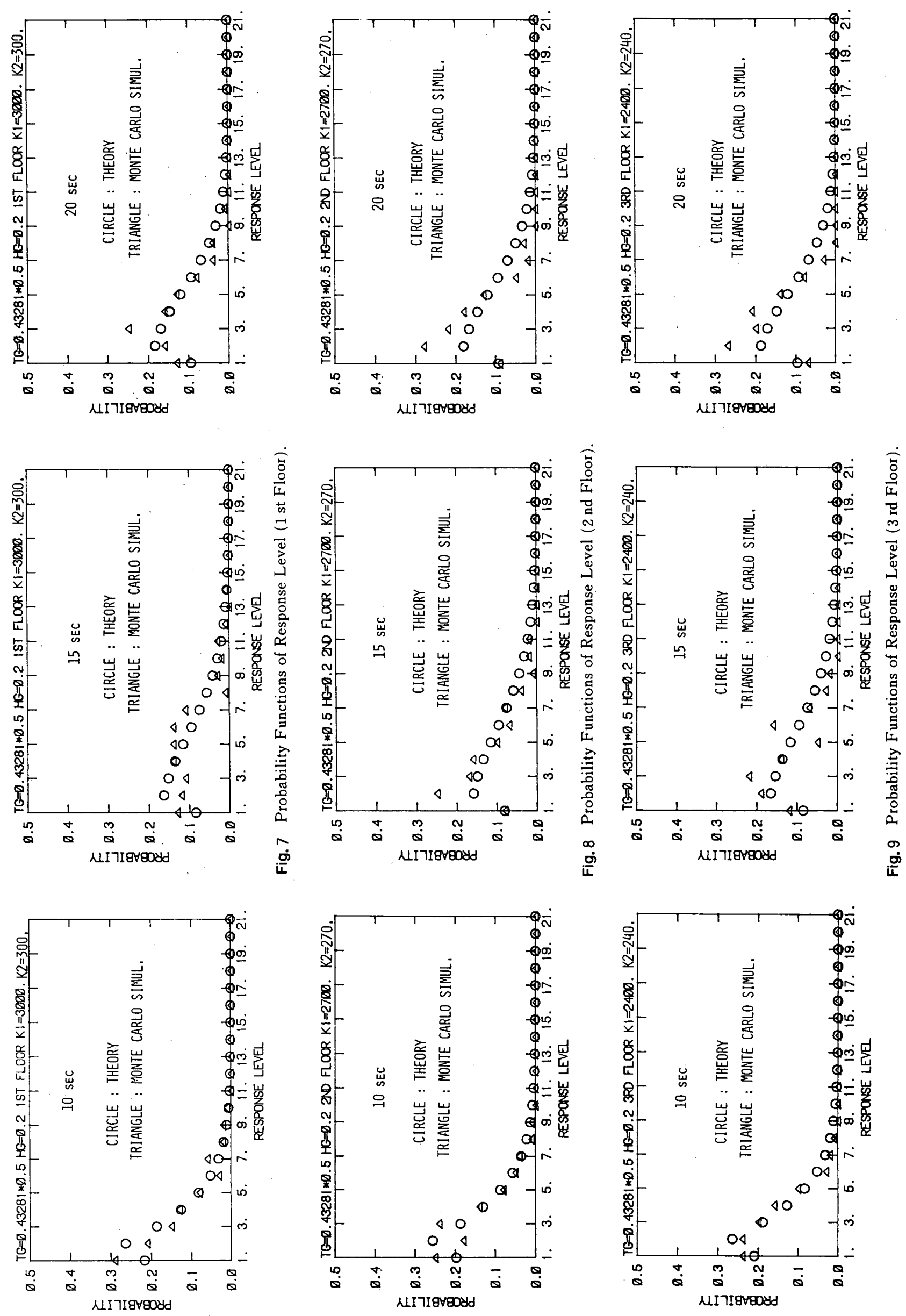

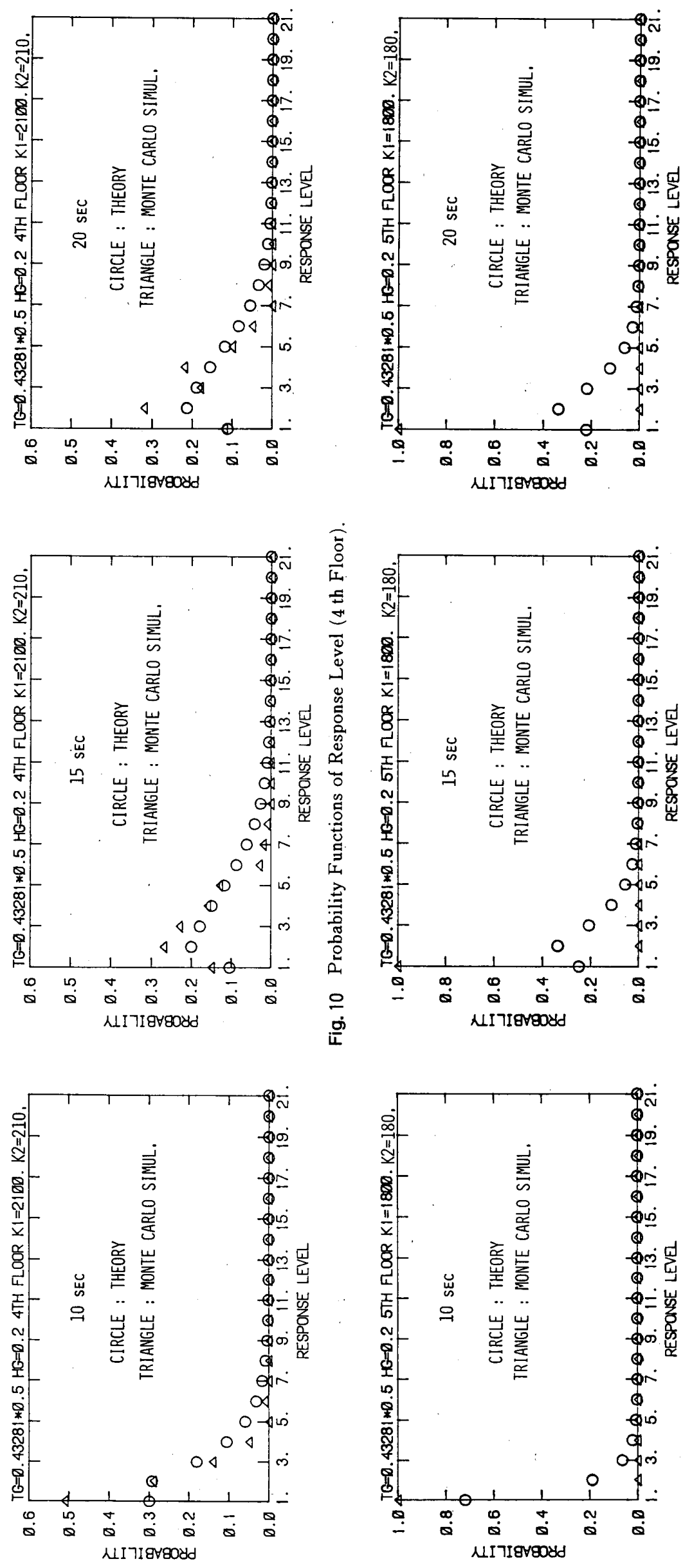

み本手法による理論解と Monte Carlo 法によるシミュレーション解 との比較検討を行う。理論解とシ ミュレーション解との比較は, 各応 答の状態に対応づけられたナンバー $\left(S_{i}\right.$ の $\left.i\right)$ を用いて，応答レベル $X_{i}$ を次式により定義し， $X_{i}$ に対す る確率分布の比較として行う。

$$
\begin{aligned}
X_{i}=\mid & i-i_{m} \mid+1 \cdots \cdots(28) \\
i & : \text { 応答の状態のナンバ- } \\
& (1 \leqq i \leqq n) \\
i_{m}: & P-\delta \text { 平面の原点を有 } \\
& \text { する応答の状態のナン } \\
& \text { バー }
\end{aligned}
$$

$X_{i}$ は, 応答の状態 $S_{\imath}$ の $P-\delta$ 平 面の原点からの離九具合を示す確率 変数であり, 応答レベルの大きさを 表す指標となる。

各質点とも応答の状態の総数 $n$ を 41 とし，応答の状態の幅 $d$ (Fig. 1 参照) を各質点の降伏変位 値の $1 / 5$ とした。この値の $n, d$ に 対して, 初通過破壊の基準となる応 答の状態 $S_{1}, S_{n}$ は，原点から塑性 率で 5.44 の位置にある。また，(3) 式右辺の $\left(t_{m+1}-t_{m}\right)$ は, すべての $m(m=0 \sim 29)$ にわたって 1 秒と した。

Figs. 7 11に，各質点について 応答レベル $X_{i}$ 上の確率分布 (確率 関数) の理論解を Monte Carlo 法 によるシミュレーション解とともに 示す。各質点とも $10,15,20$ 秒の 3 時点について示してあり, 丸が理 論解, 三角がシミュレーション解で ある。質点のナンバーは, 下から 1 , 2，….., 5 である (Fig. 6 参照)。 Monte Carlo 法に基づくシミュレー ション解は，模擬入力波 100 波によ る応答波群の統計処理を各時点にお ける集合平均により算出したもので あり, 応答計算は線型加速度法に 拠った。

Figs. 7〜11 の結果をみると，1〜 4 質点については理論解はシミュ レーション解に対して全体的にやや 安全側の評価になっているが，工学 的精度においてはよく対応している 
といえる。特に入力の減衰部分にある 20 秒時の確率分 布が，主要動の最終時刻である 15 秒時の確率分布に対 して, $P-\delta$ 平面の原点方向に指向している傾向をシミュ レーション解は示しているが，これを理論解が再現して いる点は, 理論解の妥当性を考える上で重要である。最 上にある 5 質点目については, 理論解はシミュレーショ ン解に対し過大に安全側の評価をしており，両者はよい 対応を示していない。本手法においては，対応する線形 系の確率応答の情報とエネルギー一定則から，各層の推 移マトリックスを近似しているが，最上層における理論 解の過大評価は, 最上層へのエネルギー分配が過大で あったことを意味している。この点については，履歴型 多質点系を規定するシステムパラメータとの関連も含め て，今後の検討課題としたい。しかしながら，この点を 除けば，理論解は全体としてシミュレーション解をよく 再現しているといえる。

\section{4. 結語}

本報告では, 従来 white noise 入力, 履歴型 1 質点系 に対し適用されていたマルコフ連鎖確率モデルによる履 歴系のランダム応答解析手法を, non-white noise 入力, 履歴型多質点系へ適用する場合の理論的拡張を行い, 基 礎固定せん断型の Bilinear 型 5 質点系が, 振幅非定常 な filtered Gaussian white noise (Bilinear 系に対応す る線形系の 1 次固有周期に対し，相対的に短周期成分が 卓越)を受ける場合について, その理論解をMonte Carlo 法に基づくシミュレーション解と比較検討した。 この手法によるランダム応答理論解は, 各質点の $P-\delta$ 平面に設定された応答の状態 $\boldsymbol{S}$ 上の非定常確率関数 (応 答ベクトル）により表されるが, シミュレーション解と の比較においては，これと同等な応答レベル $\boldsymbol{X}$ 上の非 定常確率関数により行った。その結果, 最上にある質点 の応答が安全側に過大評価する点を除いて, 各質点とも 理論解はシミュレーション解とおおむねよい対応を示し た。特に，入力の減衰部分にあたる時点の確率分布が， 主要動の最終時点の確率分布に対し, $P-\delta$ 平面の原点 方向に指向する傾向を理論解が再現している点は興味深 い。
今回扱った入力は, 履歴型多質点系に対応する線形系 の 1 次固有周期に対して相対的に短周期成分が卓越する non-white noise であったが，長周期成分が卓越する場 合についても，目下検討中であり，別途報告する予定で ある。また, 周波数非定常入力に対しても今後本法を適 用することを考えていきたい。

\section{参考文献}

1）和泉正哲, 渡辺孝英, 勝倉 裕, 木村正彦：マルコフ連 鎖確率モデルによる履歴構造物のランダム応答解析, 日 本建築学会論文報告集, 第 324 号, 昭和 58 年 2 月, pp. 18-27.

2）和泉正哲，木村正彦：振幅非定常入力を受ける履歴系の ランダム応答解析, 日本建築学会論文報告集, 第 335 号, 昭和 59 年 1 月, pp. 15-21.

3）浅野幸一郎：弾塑性形履歴特性を有する質点構造物の確 率統計的地震応答 その3. 擬定常 Non-white Noise 入 力を受ける 1 自由度系, 日本建築学会論文報告集, 第 257 号, 昭和 52 年 7 月, pp. 67-73.

4) M. Ozaki, S. Yasuda and M. Ishii : A Practical Method for the Earthquake Response Analysis of Multi-story Structures with Degrading Stiffness Systems by Random Vibration Theory, Trans. of A.I. J., No. 336, Feb., 1984, pp. 21-33.

5) H. Tajimi : A Standard Method of Determining the Maximum Response of a Building Structure During an Earthquake, Proc. of 2 nd WCEE, Tokyo, Vol. 2, July, 1960, pp. 781-798.

6) A.D. Kiureghian : Structural Response to Stationary Excitation, Journal of the Engineering Mechanics Division, ASCE, Vol. 106, No. EM 6, Dec., 1980, pp. 1195-1213.

7) S. Krenk, H. O. Madsen and P. H. Madsen : Stationary and Transient Response Envelopes, Journal of Engineering Mechanics, Vol.109, No.1, Feb., 1983, pp. 263278.

8) T. K. Caughey and H. J. Stumpf: Transient Response of a Dynamic System Under Random Excitation, Journal of Applied Mechanics, Dec., 1961, pp.563-566.

9) W.D. Iwan : A Distributed Element Model for Hysteresis and Its Steady-State Dynamic Response, Journal of Applied Mechanics, Dec., 1966, Vol.33, No. 4, pp. 893-900. 


\section{SYNOPSIS}

UDC : $624.042 .7: 620.1$

\section{RANDOM RESPONSE ANALYSIS OF HYSTERETIC MDOF SYSTEM TO NON-WHITE EXCITATION}

by Dr. MASANORI IZUMI, Professor of Tohoku University and MASAHKO KIMURA, Graduate Student of Tohoku University, Members of A.I. J.

It is necessary to estimate a probabilistic seismic safety of building structures to a non-white excitation, because most of expected earthquake motions will have non-white spectral properties for the existence of the ground.

In this paper a random response analysis method by Markov chain stochastic model has been extended to nonwhite excitation input and hysteretic MDOF system case and this extended stochastic model has been applied to a shear type 5-DOF bilinear system to amplitude-nonstationary non-white noise whose predominant period is shorter than that of a linear system corresponding to the hysteretic system.

This theoretical method gives a nonstationary probability function $P(S)$ of discretized response state $S$ in force-deflection plane. The comparison between theoretical results and simulation ones based on Monte Carlo method has been made by a nonstationary probability function $P(X)$ of response level $\mathrm{X}$, which is equivalent to $P(S)$. The theoretical results have showed relatively good agreements with simulation ones except for overestimation of the top floor ( 5 th floor).

It is expected that this stochastic method will be extended to inputs with longer period components or with frequency non-stationarity. 